Journal of Economics and Behavioral Studies

Vol. 2, No. 3, pp. 86-91, Mar 2011

\title{
Work-Addiction: A Poison by Slow Motion
}

\author{
*Parul Sharma, Jyoti Sharma \\ School of Business, College of Management, PRO Shri Mata Vaishno Devi University, Gandhi Nagar, Jammu \\ *parul2882sharma@yahoo.co.in
}

\begin{abstract}
Today's professionals work long hours for a variety of reasons and are dominated by increasing work pressures, tough competitors and day to day challenges. Due to this they are getting addicted to work. Addiction to work is a new concept and the effect of work addiction is more severe than the people realize. Keeping this in view, the paper attempts to throw light on the underlying dimensions of work addiction and depicts the consequences of work addiction. The study also suggests some preventive and remedial measures to overcome/reduce the outcomes of this addiction to work.
\end{abstract}

Key Words: Counseling, Emotional Imbalance, Enthusiastic Addicts, Work Life Balance, Work Addicts.

\section{Introduction}

The people of present era are living in a chaotic transition period of a new age which is defined by global competition, rampant changes, faster flow of information and communication, increasing business complexity, and pervasive globalization. The pace of change has become so rapid that it has taken different type of firms to be dominant and is able to mark entirely new era of business which is characterized by increasing work pressures, tough competitors, day to day challenges and so on. It has lead to the convergence of boundaries between personal and professional lives. The professionals of today has become potential victims of work addiction, which may be due to the fact that they are devoting much of their time at their workplaces and are getting engrossed in work. The balancing of personal and professional life has emerged to be one of the major dilemmas being faced by the professionals of present era. The study puts forward the positive and negative outcomes of work addiction and tries to suggest some measures to overcome the same. The paper is divided into two sections, sections I portrays the theoretical framework of work addiction followed by section II, which throws light on the consequences of work addiction. And section III suggests the preventive measures to overcome the consequences of work addiction.

\section{Theoretical Framework of Work Addiction}

The term work addiction coined by Oates in 1968 is equated akin to addiction to alcohol in excess and refered as to people whose needs to work has become so exaggerated that it may constitute a danger to their health, personal happiness, interpersonal relations and social functioning (Oates, 1968). Another definition proposed by Spence and Robbins (1992), stated that the common element in the discussions of workaholism is that the affected individual is highly committed to work and devoting a good deal of time to it. Some writers view work addiction as unhappy, obsessive, tragic figures, which are not performing their jobs well and are creating difficulties for their co workers (Naughton, 1987 and Oates, 1971). A work addict has a single aim in mind i.e. to work more and more and stretches himself to the point of exhaustation and is constantly worried about meeting deadlines and achieving success and so on.

The most common types of work addicts are work enthusiasts and enthusiastic addicts (Burke, 2002). Both of these addicts had different levels of scores on the three dimensions identified by Spence and Robbins (1992), namely, work involvement, a feeling driven to work and work enjoyment. They mentioned that work enthusiasts had high scores on work involvement and work enjoyment and low on drive to work. In contrasts, enthusiastic addicts had high scores on all the three components. Out of the two types of work addicts, enthusiastic addict proves to be work addict (Burke et al. 2008). It is not that enthusiastic addict develop work addiction overnight. A person is seen to develop work addiction over a period of time normally in three 
stages. In the first stage of work addiction, the person is constantly busy and tends to take on more and more work than his capability. He or she puts in lots of extra hours and will not find time to take days off. In the middle stage of work addiction the person begins to distant himself from personal relationships. He/She becomes emotionally attached to his work than to family, friends or other interests. He/ She may begin to notice physical problems, such as, insomnia or weight loss and may feel tired all the time. In the final stage, the work addict would begin to experience more serious physical, emotional and social problems. He might develop chronic headaches, high blood pressure, ulcers, depression and anxiety and so on (Parker, 2011). At the end of the final stage of work addiction, the individual has totally lost touch with the matters of personal life. He/ she become alienated from it and fail at the personal front (Snir \& Harpaz, 2004).This addiction to work can affect the life of an individual in a positive manner (Korn et al. 1987; Machlowitz, 1980; Sprankle et al. Ebel, 1987) as well as in negative manner (Killinger, 1991; Schaef and Fassel, 1988). Porter (2005) has attempted to throw light on positive and negative workplace phenomenon and attempted to make compatible approaches to work addiction.

\section{Figure 1: An overview of various approaches to the study of Workaholism}

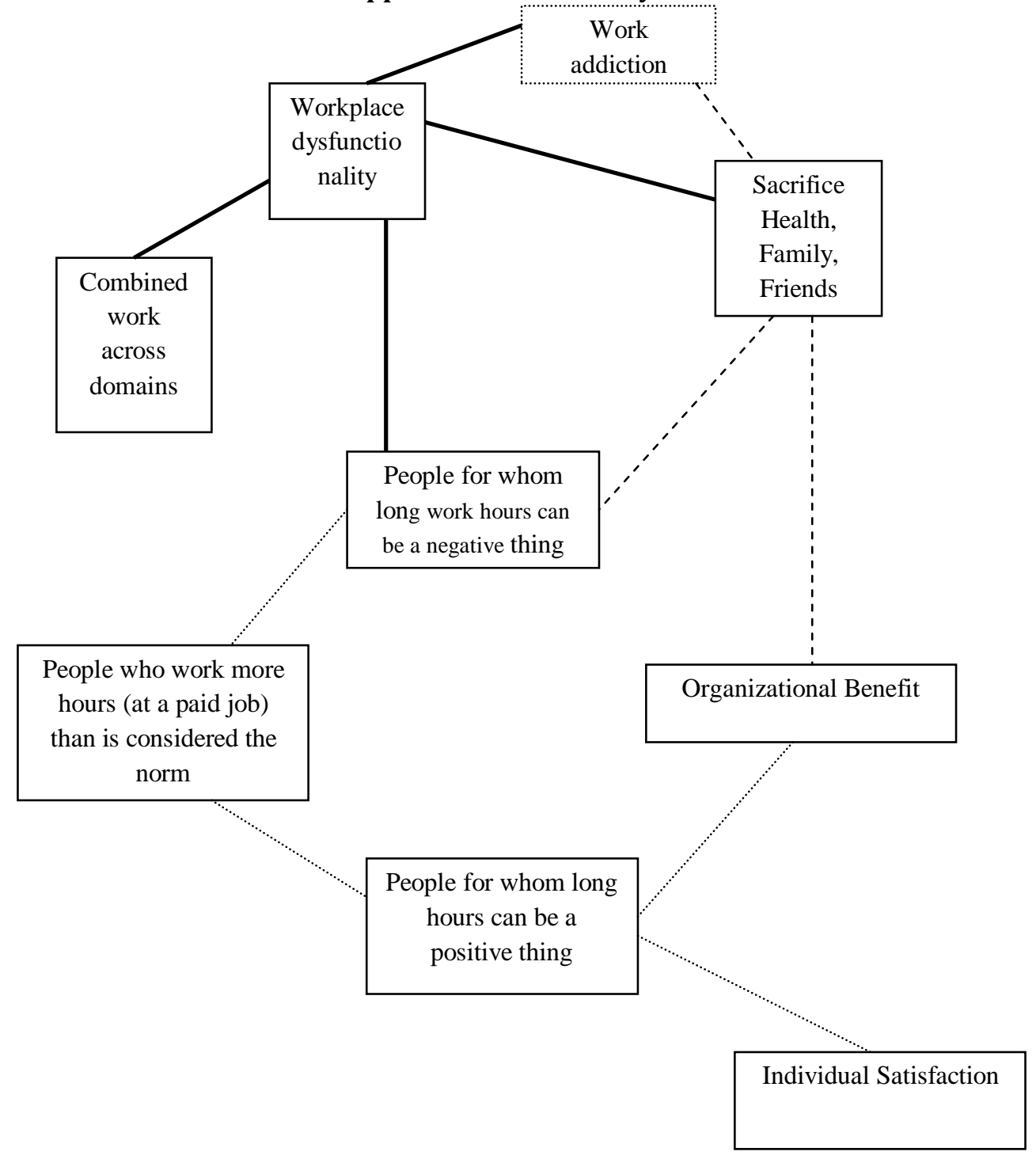

Source: Porter (2005) - Profiles of Workaholism among High- tech Managers 
The figure 1 reveals that the dotted lines connect those issues to the researchers who take a broad definition of workaholism as their starting point usually hours worked as the primary criterion. The solid lines connect to those who considered work addiction as a negative workplace phenomenon (Burke, 1999; McMillan et al. 2002; Taris et al. 2005). Further, the dashed lines connect to those issues to the researchers who consider that sacrificing health, family and friends for work is common among workaholics.

\section{Consequences of Work addiction}

Very few studies have shown the positive effects of work addiction at the workplaces. Burke (1999) found that one of the types of work addicts i.e. enthusiastic addict, shows high scores on all the three dimensions identified by Spence \& Robbins (1992) i.e. work involvement, feeling driven to work and work enjoyment. Machlowitz (1980) offered a different picture of workaholics and indicated them as very satisfied, productive and healthy individuals. She preferred to view work addiction as an approach or an attitude to working rather than as the amount of time spent at work, since workaholics continue to think about work even when they are not working.

In contrast the work addiction has given birth to various negative effects (Robinson, 2000) and it may cause physical symptoms e.g. ulcers, chest pain and even death (Fassel, 1990). Besides, the adverse effect on the health status workaholics as compared to non-workaholics (McMillan \& O' Driscoll, 2004), workaddictors' also face threat to their work life, personal, social and psychological well- being (Burwell \& Chen, 2002). The one of negative effects of work addiction is stress and it has become a way of modern life due to hassles, deadlines, frustrations and demands of the present work environment. If an individual is constantly undergoing stress, the mind and body suffers and causes various other psychological and psychosomatic problems. Stress may also pass on from family members of one generation to the next generation (Gini, 1998) and its prolonging suffering may further lead to psychosomatic disorders. Aziz and Zickar's (2006) findings has also supported that workaholism is found to be correlated with work stress. Workaholics face stressinduced illnesses, chronic fatigue, and increased anxiety levels (Caproni, 1997; Robinson, 1998; Bartolome, 1983; and Killinger, 1991). Further, psychological and psychosomatic symptoms and health problems generated due to work addiction had also examined work addiction effects on the gender basis and were found more in females than the male counterparts (Burgess et al. 2006 \& Koyuncu, et al. 2006). The emotional exhaustion is found to be more in work addicts than non-work adductors (Burke et al. 2004).

Another negative consequence of work addiction is imbalance in the personal and the professional life. This is the direct outcome of work addiction which drains off the balance between work and personal life. Work addicts divert their energy to work, gradually neglect their family and ultimately distant themselves from the personal life. This imbalance fails to build a strong personal foundation at home. If an individual devotes much of his/her time at workplace, the personal life will get imbalanced and the family and children would feel deserted (Burke, 2001; Kanai \& Wakabayashi, 2004 \& Chamberlain \& Zhang, 2009). The workaholics have no time at all for any outside relationships including their family, friends and even God (Minirth et al. 1981). They experience more marriage failures that commonly ended up in divorce (Sprull, 1987) and tend to experience a higher rate of marital failure (Klaft \& Kleiner, 1988; L'Abate \& L'Abate, 1981). Robinson et al. (2001) suggested that spouses of workaholics have higher levels of marital estrangement and less positive affect than the spouses of non- workaholics which interfere with intimate relationships and positively correlated with family dysfunction (Robinson and Post, 1995). Consequently they experience more work-life conflicts and less life satisfaction (Bonebright et al. 2000).

The poor social functioning of work addictors has also proven to be poor (Robinson, 2000) and have reported disproportion between work and social life (McMillan \& O'Driscoll, 2004). They are so much involved in their work that they get restricted to the work place only. Not having easy access to the potential new friends becomes a big barrier for work addicts in creating a social circle. Thus their interaction with the other people becomes negligible. The next consequence of work addiction is in career growth. Work addicts are not satisfied by their career prospects (Burke, 2000 and Burke, et al. 2006) and can be considered as the liability for the organization. Individual are constantly being evaluated on their potential for advancement. If a person is constantly dealing with uneasiness due to overwork in his life, it will become difficult for him to 
concentrate on his work. This would add serious effect in their career growth as they may not be promoted. The above emphasizes the negative effects of work addiction. The work addicts are facing health and personal life imbalances and are not happy in their lives. They are going through tension and unhealthy atmosphere in their personal as well as professional lives. This behavior caused their family and children to suffer and, in turn, affects their social and professional lives (Snir et al. 2006).

\section{Conclusion and Recommendations}

In corporate environment, many times work addiction is encouraged, supported and compensated for unhealthy patterns for short term gains in terms of productivity and profits. The management donot pay attention to the fact that the employees in the organization are often referred as the internal customers of the organizations. Understanding the attitudes, behavior, motivation, feelings of employees becomes an elementary concern for most of the organizations. However, the employees play an important role in shaping and directing the organizations productivity and achievement of goals and its overall success (Russo \& Waters, 2006). Thus the organization can play an important role in shaping the right type of attitude, work behavior in employees which can help in overcoming the negative causes associated with this new concept of present era. To do this organizations should encourage due vacations because it gives time to an individual to think more strategically towards his/her career growth. With this he/she will be away from day to day work loads and think for his/ her career. Moreover, management should set objectives which are effective and realistic. With this the individual will be able to manage his/her workload effectively and will prioritize their time according to its importance so that time can be given to personal lives after finishing the work. To promote work- family balance, the management can take a proactive Counseling approach which may be an effective tool to deal with the employees suffering from work addiction. It can judge demoralizing effects of work addiction at the work place (Robinson, 2000, Naughton, 1987; Seybold and Salomone, 1994). Therefore educating work addicts on the perpetuating associated effects like stress, imbalance between the work and personal lives can do some wonder in this context. Counselors can hold seminars or workshops on healthy working. Lastly, management can also organize various activities like Family Day or picnics so that they could get enough time with their family members and hence their social life is also encouraged. Robinson (1998) revealed that family involvement is another vehicle for assisting workaholics.

From the perspective of an individual, in order to cope up with the stress the individual can practice yoga and meditation .It makes the body more flexible and helps to relax even in the midst of a stress stricken environment. Practicing yoga and meditation can be helpful for an individual to become more energetic, happier and peaceful. Moreover yoga can also be helpful in dealing with the psychological and psychosomatic problems like anxiety, headaches, etc. Various organizations including IBM, Xerox, AT\&T, Nike, Forbes, Apple, Pepsico, General Electric etc. (Casey, 2002) offers yoga, meditation and mind body work in-house programmes for its employees. Moving on to physical benefit, individuals can do regular exercises, which will help him in developing and maintaining physical fitness. Frequent and regular physical exercises boost the immune system and help to prevent various diseases, such as, heart diseases, psychological diseases, etc. Moreover, exercising prevents depression and improves mental health by relieving stress and anxiety. There is no doubt that regular exercising can keep body and mind fit but there is a need to have a healthy and balance diet. Regular exercise with balance diet together keeps healthy. To reiterate, it can be said that both organizations' as well individuals' initiatives have to go unisom to deal with the problem of work addiction as in the initial stage of work addiction, the negative effects may not be visible and it may be seen as the positive symptom. But over a period of time as the work addict passes through the middle and the last stage, the person may not remain productive for an organization as well as the personal life.

\section{References}

Gini, A. (1998) "Working Ourselves to Death: Workaholism, Stress, and Fatigue”, Business and Society Review, 100/101: 45.

Aziz, S. \& Zickar, M. J. (2006) "A cluster analysis investigation of workaholism as a syndrome", Journal of Organizational Health Psychology, 11 (1): 52-62.

Bartolome, F. (1983) "The work alibi: when it's harder to go home", Harvard Business Review, 61 (2): 67-74. 
Bonebright, C. A., Clay, D. L. \& Ankenman, R. D. (2000) "The relationship of workaholism with work-life conflict, life satisfaction and purpose in life", Journal of Counseling Psychology, 47(4): 469-477.

Burgess, Z., Burke J. R. and Okerklaid F. (2006) "Workaholism among Australian psychologists: gender differences", Equal Opportunities International, 25(1): 48-59.

Burke J. R., Richardsen M. A. \& Mortinussen, M. (2004) “Workaholism among Norwegian Managers”, Journal of Organizational Change Management, 17(5):459-470.

Burke, R. J. (1999) "Workaholism among Women Managers: Work and Life Satisfactions and Psychological Well- Being", Equal Opportunities International, 18(7):25.

Burke, R.J. (2001) “Workaholism in organizations: the role of organizational values", Personnel Review, 30(6): 637-645.

Burke, R.J. (2002) "Do workaholics prefer demanding, aggressive and results- oriented organizational cultures", Career Development International, 7(4): 211.

Burke, R.J. (2000) "Workaholism in organizations: psychological and physical well-being consequences" Stress Medicine, 16: 11-16.

Burke, R. J., Burgess, Z. \& Fallon, B. (2006) "Workaholism among Australian female managers and professionals" Equal Opportunities International, 25(3), 200-213.

Burke, R., Koyuncu, M. \& Fiksenbaum, L. (2008) "Workaholism, work and extra satisfactions and psychological well being among professors in Turkey", Cross Cultural Management: an International Journal, 15(4): 353-366.

Burwell, R., \& Chen, C. P. (2002) "Applying REBT to workaholic clients" Counseling Psychology Quarterly, 15(3): 219-228.

Caproni, P. J. (1997) “Work/life balance: You can't get there from here” Journal of Applied Behavioral Science, 33: 46-56.

Casey, C. (2002) "Critical analysis of organizations: theory, practice, revitalization", Sage Publications India Pvt. Ltd., Greater Kailash-I, New Delhi.

Chamberlain, C.M \& Zhang, N. (2009) "Workaholism, Health and Self Acceptance", Journal of Counseling and Development, 87(2):159.

Fassel, D. (1990) "Working ourselves to death: The high costs of Workaholism, the rewards of recovery" San Francisco, CA: Harper Collins.

Kanai, A. \& Wakabayashi, M. (2004) "Effects of economic environmental changes on job demands and workaholism in Japan", Journal of Organizational Change Management, 17 (5): 537.

Killinger, B. (1991) “Workaholics: The Respectable Addicts, Simon \& Schuster, New York, N. Y.

Klaft, R. P. \& Kleiner, B. H. (1988) “Understanding workaholics. Business Atlanta, 38(3): 37.

Korn, E. R., Pratt. G. J. and Lambrou, P. T. (1987) "Hyper-performance: The AIM Strategy for Releasing Your Business Potential, John Wiley, New York, NY.

Koyuncu M. Burke J. R. \& Fiksenbaum, L. (2006) "Work experience and satisfaction of male and female professors in Turkey: signs of Progress?" Equal Opportunities International, 25 (1): 38-47.

Koyuncu, M., Burke, R.J., Fiksenbaum, L., (2006) "Work engagement among women managers and professionals in a Turkish bank: Potential Antecedents and Consequences", Equal Opportunities International, 25(4): 299-310.

L'Abate, L. \& L'Abate, B. L. (1981) “Marriage: The dream and the reality author”, Family Relations, 30(1): 131136.

Machlowitz, M. (1980) “Workaholics: Living with Them, Working with Them, Addison-Wesley, Reading, M. A.

McMillan, L. H. W. \& O'Driscoll M. P. (2004) “Workaholism and Health: Implications for organizations” Journal of Organizational Change Management, 17(5): 509-519.

McMillan, L. H. W., O'Driscoll, M. P. and Marsh, N. V. (2002) "A multifaceted validation study of Spence and Robbins (1992) workaholism battery", Journal of Occupational and Organizational Psychology, 75(3): 357-68.

Minirth, F., Meier, P., Wichern, F., Brewer, B. \& Skipper, S. (1981) "The workaholic and his family: An inside look", Grand Rapids, MI: Baker Book House.

Naughton, T. J. (1987) "A conceptual view of Workaholism and implications for career counseling and research", The Career Development Quarterly, 180-187.

Oates, W. E. (1968) "On being a workaholic: A serious jest" Pastoral Psychology, 19: 16-20.

Oates, W. E. (1971) “Confessions of a Workaholic: The facts about work addiction”, New York: World. 
Porter, G. (2005) “Profiles of workaholism among high-tech managers”, Career Development International, 11: 5.

Parker, W. (2011) "Recovering from Workaholism-The Stages of Work addiction" About.com Guide, accessed on 2-01-2011.

Robinson, B. E. \& Post, P. (1995) "Work addiction as a function of family of origin and its influence on current family functioning", The Family Journal, 3: 200-206.

Robinson, B. E., Carroll, J. J., \& Flowers, C. (2001) "Marital estrangement, positive affect, and locus of control among spouses of workaholics and spouses of non-workaholics: A national study" The American Journal of Family Therapy, 29: 397-410.

Robinson, B. E. (2000), "Workaholism: Bridging the gap Between Workplace, Socio cultural, and Family Research", Journal of Employment Counseling, 37(1): 31.

Robinson, B. E. (1998) "Chained to the Desk: A Guidebook for workaholics, their partners and Children, and the Clinicians who treat Them, New York University Press, New York, NY.

Russo, J. A. \& Waters, L. E. (2006) "Workaholic worker type differences in work-family conflict", Career Development International, 11(5): 418-439.

Schaef, A. W. \& Fassel, D. (1988) “The Addictive Organization”, Harper \& Row, San Francisco, C. A.

Seybold, K. C. and Salamone, P. R. (1994) "Understanding workaholism: a view of causes and results", Journal of Personality Assessment, 58: 168-78.

Snir, R., Harpaz, I. \& Burke, R. (2006) "Work aholism in organizations: new research directions", Career Development International, 11(5): 369-373.

Snir, R. \& Harpaz, I. (2004) "Attitudinal and Demographic Antecedents of Workaholism", Journal of Organizational Change Management, 17(5): 520-536.

Spence, J. T. \& Robbins, A. S. (1992) "Workaholism definition, measurement and preliminary results", Journal of Personality Assessment, 58: 160-78.

Sprankle, J. K. \& Ebel, H. (1987) “The Workaholic Syndrome”, Walker Publishing, New York, N.Y.

Sprull, G. (1987) “Work fever” Training and Development Journal, 41: 41-45.

Taris, T. W., Schaufeli, W. B. \& Verhoeven, L. C. (2005) "Workaholism in The Netherlands: Measurement and implications for job strain and work- non-work conflict", Applied Psychology: in International Review, 54(1), 37-60. 